\title{
Risk of lymphoma subtypes by occupational exposure in Southern Italy
}

\author{
Giovanni Maria Ferri ${ }^{1,6^{*}}$ D , Giorgina Specchia ${ }^{2}$, Patrizio Mazza ${ }^{3}$, Giuseppe Ingravallo ${ }^{4 \dagger}$, Graziana Intranuovo ${ }^{1}$, \\ Chiara Monica Guastadisegno ${ }^{1+}$, Maria Luisa Congedo ${ }^{1 \dagger}$, Gianfranco Lagioia ${ }^{1+}$, Maria Cristina Loparco ${ }^{1 \dagger}$, \\ Annamaria Giordano ${ }^{2+}$, Tommasina Perrone ${ }^{2 \dagger}$, Francesco Guadio ${ }^{2+}$, Caterina Spinosa ${ }^{3 \dagger}$, Carla Minoia ${ }^{3+}$, \\ Lucia D'Onghia $^{3+}$, Michela Strusi ${ }^{3 \dagger}$, Vincenzo Corrado ${ }^{1 \dagger}$, Domenica Cavone $^{1 \dagger}$, Luigi Vimercati $^{1 \dagger}$, \\ Nunzia Schiavulli ${ }^{1+}$ and Pierluigi Cocco $^{5}$
}

\begin{abstract}
Background: Occupational exposure is known to play a role in the aetiology of lymphomas. The aim of the present work was to explore the occupational risk of the major B-cell lymphoma subtypes using a case-control study design.

Methods: From 2009 to 2014, we recruited 158 lymphoma cases and 76 controls in the provinces of Bari and Taranto (Apulia, Southern Italy). A retrospective assessment of occupational exposure based on complete work histories and the Carcinogen Exposure (CAREX) job-exposure matrix was performed.

Results: After adjusting for major confounding factors, farmers showed an increased risk of diffuse large B-cell lymphoma $(\mathrm{DLBCL}$ ) [odds ratio $(\mathrm{OR})=10.9(2.3-51.6)]$ and multiple myeloma $(\mathrm{MM})[\mathrm{OR}=16.5(1.4-195.7)]$; exposure to the fungicide Captafol was significantly associated with risk of non-Hodgkin lymphoma (NHL) [OR = 2.6 (1.1-8.2)], particularly with the risk of DLBCL $[O R=5.3(1.6-17.3)]$.

Conclusions: Agricultural activity seems to be a risk factor for developing lymphoma subtypes, particularly $D L B C L$, in the provinces of Bari and Taranto (Apulia Region, Southern Italy). Exposure to the pesticides Captafol, Paraquat and Radon might be implicated.
\end{abstract}

Trial registration: Protocol number UNIBA 2207WELLZB_004 registered 22/09/2008.

Keywords: Lymphomas, Occupational exposure, CAREX matrix, Pesticides, B-cell lymphoma subtypes, Case-control study

\section{Background}

According to 2007-2010 data from the Italian Association of Cancer Registries/Associazione Italiana Registri Tumori (AIRTUM), the estimated standardized incidence rate of haemolymphopoietic cancers was lower in Southern than in Northern Italy; this difference was

\footnotetext{
* Correspondence: giovannimaria.ferri@uniba.it Giovanni Maria Ferri, Giorgina Specchia, Patrizio Mazza, Graziana Intranuovo and Pierluigi Cocco jointly supervised this work.

${ }^{\dagger}$ Equal contributors

"Department of Interdisciplinary Medicine (DIM), Section "B. Ramazzini", Regional University Hospital "Policlinico - Giovanni XXIII", Unit of Occupational Medicine, University of Bari, Piazza G. Cesare, 11, 70124 Bari, Italy ${ }^{6}$ Interdisciplinary Department of Medicine (DIM), University Hospital. Policlinico-Giovanni XXIII, University of Bari, Piazza Giulio Cesare, 11, 70124 Bari, Italy Full list of author information is available at the end of the article
}

more significant for non-Hodgkin lymphoma (NHL), multiple myeloma (MM) and chronic lymphocytic leukaemia (CLL) and less significant for Hodgkin lymphomas (HL) [1]. The Apulia areas of reference were the provinces of Bari and Taranto. The estimated standard rates of incidence $(\times 10,000)$ of CLL in Taranto Province were 12.8 for males and 12.1 for females. In Bari Province, the rates were 18.1 for males and 11.9 for females. In the Apulia region, they were 14.7 for males and 9.1 for females. The estimated standard rates of incidence of HL were 3.9 for males and 4.1 for females in Taranto Province, 4.5 for males and 5.8 for females in Bari Province and 3.8 for males and 3.7 for females in the Apulia region. The estimated standard rates of incidence of NHL were 14.6 for males and 9.3 for females in Taranto Province, 20.7 for males and 15.0 for females in Bari Province, and 14.7 for males and 10.6 
for females in the Apulia region. The estimated standard rates of incidence of MM were 5.2 for males and 4.1 for females in Taranto Province, 7.4 for males and 6.1 for females in Bari Province and 6.3 for males and 4.8 for females in the Apulia region [2].

The north/south gradients might suggest various causes, including a lesser prevalence of exposure to occupational and environmental carcinogens and to tobacco smoking and a higher prevalence of protective factors such as healthier food habits and a younger age at first pregnancy in Southern Italy. Typical Mediterranean diet items, in particular fruits and vegetables, showed an inverse association with NHL risk [3]. Furthermore, a case-control study of the risk of $\mathrm{MM}$ among women in the International Multiple Myeloma Consortium [4] showed a decreased risk of follicular lymphoma (FL) with an increasing number of pregnancies and an association between FL and hormonal contraception [5]. A lower rate of participation in cancer screening programmes in the southern regions of Italy might also reflect a lower detection rate. In terms of mortality, the previously reported North-south gradient has been gradually decreasing in recent years [1]. The observed difference in Taranto and Bari could be explained by different regional industrial activities and other studied factors.

The role of chemical agents (pesticides, solvents), ultraviolet radiation and infectious agents has been extensively studied [6-9].

Male farmers tend to have lower overall cancer incidence and mortality, which might be due to their lower smoking prevalence and increased physical activity [10-13]. However, the risk of certain cancers, including lymphohaematopoietic cancer, has been reported to be increased among farmers $[10,14,15]$.

Rieutort et al. found that NHL was associated with various occupational activities and exposures; among them, those involving agricultural or industrial sectors and solvents or pesticides were highlighted, with the highest number of publications and the strongest association with NHL risk [16].

The aim of this case-control study is to assess the association between occupational activities and lymphoma subtypes and to study the occupational risk factors involved in the occurrence of those lymphoma subtypes in the provinces of Taranto and Bari in the Apulia Region (Southern Italy) using the "Carcinogen Exposure" (CAREX) matrix for assessing occupational carcinogen exposure.

\section{Methods}

This study reports the activity of a unit of "The Multicentre Italian Study on Gene-Environment Interactions in Lymphoma Etiology" financed by the Italian Projects of National Interest (PRIN) and the Italian Association for Cancer Research (AIRC) and participated in the InterLymph Consortium initiated by the U.S. National Cancer Institute from 2009 to 2014 and in the GenomeWide Association Study (GWAS) project. The recruitment of patients was performed in the haematology division of the University Hospital of Bari and in the haematology division of the "Moscati" Hospital of Taranto in the Apulia region (Southern Italy). The study was coordinated by the Occupational Section of the Interdisciplinary Department of Medicine (DIM), University of Bari, Italy.

\section{Study sample}

One hundred fifty-eight incident cases of lymphoma first diagnosed during the study period were included: 30 cases of HL and 128 cases of NHL [35 cases of diffuse large Bcell lymphoma (DLBCL), $26 \mathrm{FL}, 42 \mathrm{CLL}, 3$ mantle cell lymphoma, 8 small B-cell lymphoma (SBCL), $11 \mathrm{MM}$, and 3 mucosa-associated lymphoma tissue (MALT)]. For each case, the diagnosis was reviewed and classified using the 2008 World Health Organization (WHO) classification of lymphoma [17]. During the same period, 76 controls were enrolled and were selected by a matching method (age at first diagnosis, sex and residence); however, due to the small number of controls, no matching analysis was performed. The selection of population controls was performed by accessing the assisted regional register and identifying a list of subjects of the same sex, same age class, and same province of residence (provinces of Bari and Taranto) as the cases. Subsequently, using a simple randomization method, controls were identified and contacted by phone. Outpatient controls were recruited at the ophthalmological and orthopaedic outpatient clinic of Bari Hospital and Taranto Radiology, after the inclusion criteria were verified. In-hospital controls were recruited from the departments of the ophthalmological clinic and the orthopaedic clinic of Bari and Taranto. The inclusion criteria for controls were those without a diagnosis of malignant neoplastic diseases, Acquired Immuno-Deficiency Syndrome (AIDS), eye diseases, thyroid disease, diabetic retinopathy, autoimmune diseases, allergic diseases, viral hepatitis, haematological preneoplastic diseases, such as monoclonal gammopathy of undetermined significance (MGUS), bone marrow aplasia, or myeloproliferative syndromes; similarly, patients undergoing organ transplants were not eligible for inclusion as controls. Cases and controls were recruited from within the same geographic area. The participation rates were $50 \%$ for the population controls, $80 \%$ for hospitalized controls, and $75 \%$ for cases. The population controls, who were selected from among healthy subjects from the regional health service database, were obviously less sensitized. Different methods of control recruitment in the case-control studies were studied, and the method based on the regional health system showed lower compliance $(42 \%)$ than the method based on the 
involvement of general practitioners (57\%) [18]. All participating cases and controls signed an informed consent form, which described the aims and methods of the study. They all provided a $40 \mathrm{ml}$ blood sample for the biological portion of the study, which was used to study the gene/environment interaction with the assessment of biological exposure parameters (serum polychlorinated biphenyls [PCB], aryl hydrocarbons receptors [AHR], lymphocytic oxidative damage by COMET assay, different genetic polymorphisms, and other biological parameters). This part of the study will produce results only in the coming years.

\section{Questionnaire and exposure assessment by CAREX}

All participating subjects were interviewed by a trained interviewer using a semi-structured questionnaire validated in the research project "Epilymph" and provided a complete work history. The questionnaire gathered information on socio-demographics; education; family history of cancer and specifically cancer of the haemolymphatic system; medical history; residential history; tobacco, alcohol and drugs use; work history; diet; physical activity; and reproductive history. We used general questionnaires and specific questionnaires for specific job activity.

The codes used to classify the job titles were allocated on the basis of qualitative crude definitions independent of matrices related to CAREX and contained in the questionnaires completed during the study. In this preliminary analysis, we used the CAREX database to assess occupational exposure to known and suspected carcinogens and pesticides. The same database was used in previous studies in Italy [19], Canada [20], Nicaragua and Panama [21]. The CAREX database sets exposure for occupational sectors. CAREX shows the frequency of reports of exposure to each of the 62 chemical and physical risk factors recognized by the International Agency for Research on Cancer (IARC) (Classes 1 and 2A) [19] for every sector. Every work activity obtained from our semi-structured questionnaires was attributed to an occupational sector that was coded by CAREX. A score was assigned to each risk factor from the report frequencies contained in the CAREX tables for that sector $[0=$ no exposure (no reports); $1=$ low exposure $(<75 \%$ of report frequency); $2=$ medium-high exposure ( $>75 \%$ of frequency of reports)]. For each job activity, the duration (number of years) was recorded. This number was multiplied by the single score. For each subject were evaluated by one to five job activities, and the related products were added. The result of the sum of the products is the CEI. The procedure was based on the following formula:

$$
\text { CEI }(\text { carex })=\Sigma(\text { Ordinal Score } * \text { Years })
$$

Categorization of the CEI was as follows: $\mathrm{CEI}=0$ [no exposure (cumulative indicator $=0$ )]; CEI $=1$ [low exposure (cumulative indicator $<=30$ )]; CEI $=2$ [medium-high exposure (cumulative indicator $>30$ )].

The CEI was not standardized because the statistics used were all non-parametric and therefore normalization was not necessary.

The analysis by job title was conducted only using the most recent job title, while the cumulative exposure was calculated over the entire work history.

Only the pathways of significant chemical substances were considered.

The power of the study was low, and the estimates, with an $\alpha$ type 1 error of $0.05 \%$, were not steady but were equally significant.

\section{Statistical analysis}

The statistical analysis was performed using the STATA 12 software, and it was mainly based on the use of nonparametric statistical distributions because of the nonGaussian distributions of a large number of studied variables.

For the comparison of proportions, the distribution of $\mathrm{Z}$ was used as indicated in the "two-sample test of proportions calculator" procedure included in the abovementioned software.

The univariate analysis was based on the "tab odds" calculations for all the studied variables.

The multivariate analysis was instead based on the use of the "unconditional logistic model", as indicated in the tables, the variables describing sister cancer familiarity, age at diagnosis, province, sex, pack/years (recoded) and level of education. No adjustment was made to the dietary habits because the univariate estimates showed no significant association with lymphoma.

\section{Results}

Cases and controls were well distributed in the main categories of age, gender, residence, education level, and job title. However, they were predominantly more than 60 years old ( $43.7 \%$ of cases, $40.8 \%$ of controls), male $(59.5 \%$ of cases, $60.5 \%$ of controls), residents of Bari (65.2\% of cases, $67 \%$ of controls), high school graduates (34.2\% of cases, $42.2 \%$ of controls), and blue collar workers (31.7\% of cases, $31.6 \%$ of controls). Specifically, recruited individuals were mostly blue collar workers, clerks and agricultural workers. No significant difference was observed between cases and controls regarding these variables. The two groups were therefore perfectly comparable. The presence of doctors, nurses and researchers, although very low, was only observed among the cases. This finding was also described in the study of $\mathrm{t}^{\prime}$ Mannetje et al. [22] (Table 1).

\section{Univariate analysis}

The analysis of lymphoma crude risk (ORs) for all 14 occupational activities was performed (Table 2), and only 
Table 1 Distribution of the main variables between cases and controls

\begin{tabular}{|c|c|c|c|c|c|c|c|}
\hline \multirow[b]{2}{*}{ Variables } & \multirow[b]{2}{*}{ Tot } & \multicolumn{2}{|c|}{ Cases } & \multicolumn{2}{|c|}{ Controls } & \multicolumn{2}{|c|}{ Proportions test } \\
\hline & & $n$ & $\%$ & $\mathrm{n}$ & $\%$ & z & $P$ \\
\hline \multicolumn{8}{|l|}{ Age } \\
\hline Less than 20 years & 7 & 6 & 3.8 & 1 & 1.3 & 0.5 & 0.3 \\
\hline $21-40$ years & 55 & 37 & 23.4 & 18 & 23.7 & 0.0 & 0.5 \\
\hline $41-60$ years & 72 & 46 & 29.1 & 26 & 34.2 & -0.4 & 0.7 \\
\hline More than 60 years & 100 & 69 & 43.7 & 31 & 40.8 & 0.3 & 0.4 \\
\hline \multicolumn{8}{|l|}{ Gender } \\
\hline Females & 94 & 64 & 40.5 & 30 & 39.5 & 0.1 & 0.5 \\
\hline Males & 140 & 94 & 59.5 & 46 & 60.5 & 0.1 & 0.5 \\
\hline \multicolumn{8}{|l|}{ Province of residence } \\
\hline Bari & 154 & 103 & 65.2 & 51 & 67.1 & -0.3 & 0.6 \\
\hline Taranto & 67 & 44 & 27.9 & 23 & 30.3 & 0.2 & 0.4 \\
\hline Others & 13 & 11 & 7.0 & 2 & 2.6 & 0.2 & 0.4 \\
\hline \multicolumn{8}{|l|}{ Title of study } \\
\hline Degree & 38 & 27 & 17.1 & 11 & 14.5 & 0.2 & 0.4 \\
\hline High school & 86 & 54 & 34.2 & 32 & 42.1 & 0.6 & 0.3 \\
\hline Middle school & 64 & 43 & 27.2 & 21 & 27.6 & 0.0 & 0.5 \\
\hline Primary school & 46 & 34 & 21.5 & 12 & 15.8 & 0.4 & 0.3 \\
\hline \multicolumn{8}{|l|}{ Jobs } \\
\hline Housewife & 16 & 11 & 7.0 & 5 & 6.6 & 0.0 & 0.5 \\
\hline Physician & 3 & 3 & 1.9 & 0 & 0.0 & - & - \\
\hline Blue collar & 74 & 50 & 31.7 & 24 & 31.6 & 0.0 & 0.5 \\
\hline Nurse & 1 & 1 & 0.6 & 0 & 0.0 & - & - \\
\hline Teacher & 17 & 9 & 5.7 & 8 & 10.5 & -0.4 & 0.6 \\
\hline Researcher & 2 & 2 & 1.3 & 0 & 0.0 & - & - \\
\hline Craftsman/Merchant & 13 & 11 & 7.0 & 2 & 2.6 & 0.2 & 0.4 \\
\hline Agricultural workers & 18 & 14 & 8.9 & 4 & 5.3 & 0.2 & 0.4 \\
\hline White collar & 43 & 28 & 17.7 & 15 & 19.7 & -0.2 & 0.6 \\
\hline Military & 10 & 5 & 3.2 & 5 & 6.6 & -0.2 & 0.6 \\
\hline $\begin{array}{l}\text { Student/Unemployed/ } \\
\text { Retired }\end{array}$ & 3 & 3 & 1.9 & 0 & 0.0 & - & - \\
\hline Freelancer & 8 & 2 & 1.3 & 6 & 7.9 & -0.3 & 0.6 \\
\hline Technical & 5 & 2 & 1.3 & 3 & 4.0 & -0.2 & 0.6 \\
\hline Missing & 21 & 17 & 10.8 & 4 & 5.3 & - & - \\
\hline Totals & 234 & 158 & 100 & 76 & 100 & - & - \\
\hline
\end{tabular}

Legend

$Z=$ The $z$-score test for the two proportions is used when you want to know whether two groups differ significantly in some characteristics

the highest estimates (agricultural activity) were used for the multivariate analysis. The same approach was also used to analyse all other studied factors.

Lymphoma risks were analysed for 22 chemical products; none of these was statistically significant. Only higher OR levels were observed for low/medium levels of butadiene $[\mathrm{OR}=1.91(0.68-5.38)]$; low/medium levels of acrylonitrile $[\mathrm{OR}=1.70(0.60-4.83)]$; low levels of ethylene dibromide $[\mathrm{OR}=1.96(0.59-6.44)]$; low levels of ethylene dioxide $[\mathrm{OR}=2.58(0.52-12-64)]$; low levels of formaldehyde $[\mathrm{OR}=2.31(0.76-7.02)]$; low levels of nitrox dimethylamine $[\mathrm{OR}=2.58(0.52-12.64)]$; low levels of toluidine $[\mathrm{OR}=1.80(0.63-5.08)]$; medium/high styrene levels $[\mathrm{OR}=1.65(0.67-4.06)]$; low levels of tetrachloroethylene $[\mathrm{OR}=1.87(0.83-4.24)]$; low levels of trichloroethylene $[\mathrm{OR}=1.45(0.66-3.19)]$; low levels of vinyl chloride $[\mathrm{OR}=1.71(0.69-4.21)]$; low levels of PAH $[\mathrm{OR}=20.31 \quad(2.26-182.23)] ;$ and medium/high PAH levels $[\mathrm{OR}=12.50(1.16-136.4)]$. Crude risk associated with low $[\mathrm{OR}=20.3(2.3-182.2)]$ and medium-high [OR $=12.5(1.2-134.4)]$ cumulative exposure to polycyclic aromatic hydrocarbons (PAHs) showed elevated risks, but they were based on very small numbers, and the very unsteady estimates were not used.

Crude risks were also analysed for 10 physical risk factors and none of these was statistically significant. Slightly higher levels of OR were observed only for: low glass wool levels $[\mathrm{OR}=2.28(0.59-8.73)]$; low levels of ionizing radiation $[\mathrm{OR}=1.78(0.45-7.03)]$; radon medium/high levels [3.28 (0.92-11.71)]; and high levels of solar radiation [OR $=1.76(0.68-4.59)]$. Crude risks were also analysed for seven heavy metals and no significant results were obtained for any of these. There was a higher crude risk only for cobalt $[\mathrm{OR}=2.20(0.62-8.01)]$. The crude risks were analysed for nine drugs and no statistical significance was observed. Crude risks for 2 pesticides showed high OR values that were very close to statistical significance: high levels of Captafol $[\mathrm{OR}=7.05(0.90-56.16)]$; low levels of dimethilsulfate (Paraquat) $[\mathrm{OR}=2.48(0.96-6.36)]$. We also analysed the crude risks for 4 tumour familiarity that did not show any statistical significance; a higher OR was observed only for breast cancer familiarity [OR $=2.15(0.77-5.99)]$. As reported in several experiences [23-26], smoking (pack/ years) was not a significant risk factor for lymphomas.

\section{Multivariate analysis}

Table 3 shows the multivariate analysis that considered not only subjects with agricultural exposure but also industrial exposure to pesticides. Subjects exposed to Captafol showed a significant increase in risk for all lymphomas $[\mathrm{OR}=2.4(1.1-5.6)]$, in particular for NHL [OR $=2.6(1.0$ 8.2)]. Subjects exposed to low levels of Paraquat also showed an increased risk for all lymphomas $[\mathrm{OR}=2.9$ $(1.0-8.2)]$, particularly NHL $[\mathrm{OR}=2.8(1.0-8.2)]$. Medium high exposure to radon was associated with risk for all lymphomas $[\mathrm{OR}=9.5(1.2-76.8)]$ and with NHL $[\mathrm{OR}=$ $8.8(1.2-71.4)]$.

Table 4 presents a significant association between overall exposure to Captafol with NHL [OR $=2.6(1.1-$ 8.2)] and with DLBCL subtype $[\mathrm{OR}=5.3(1.6-17.3)]$. Low exposure to Paraquat was also associated with 


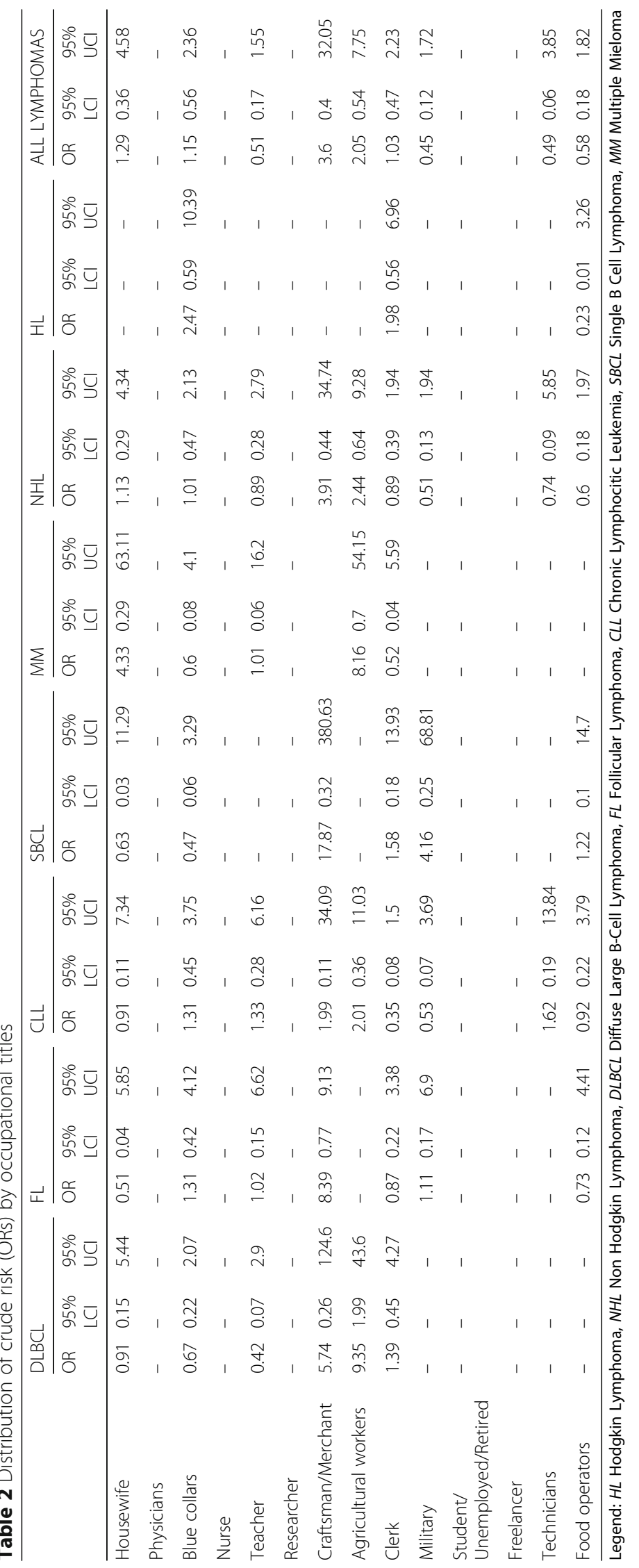




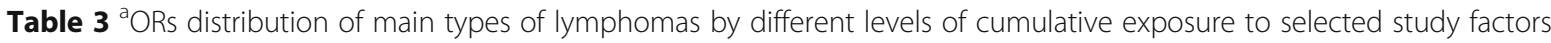

\begin{tabular}{|c|c|c|c|c|c|c|c|c|c|c|c|c|c|c|c|}
\hline \multirow{3}{*}{$\begin{array}{l}\text { Cumulative } \\
\text { exposure }\end{array}$} & \multicolumn{15}{|c|}{ Lymphoma types } \\
\hline & \multicolumn{5}{|c|}{ All lymphomas } & \multicolumn{5}{|c|}{ Hodgkin lymphomas } & \multicolumn{5}{|c|}{ Non hodgkin lymphomas } \\
\hline & Cases & Controls & $O R^{a}$ & $95 \% \mathrm{LCl}$ & $95 \%$ UCl & Cases & Controls & $\mathrm{OR}^{\mathrm{a}}$ & $95 \% \mathrm{LCl}$ & $95 \%$ UCl & Cases & Controls & $O R^{a}$ & $95 \% \mathrm{LCl}$ & $95 \%$ UCl \\
\hline \multicolumn{16}{|l|}{${ }^{\mathrm{b}}$ Captafol } \\
\hline No & 138 & 70 & 1 & - & - & 30 & 70 & 1 & - & - & 108 & 70 & 1 & - & - \\
\hline Low & 6 & 5 & 0.73 & 0.2 & 2.69 & 0 & 5 & - & - & - & 6 & 5 & 1.03 & 0.27 & 3.89 \\
\hline Medium-high & 14 & 1 & - & - & - & 0 & 1 & - & - & - & 14 & 1 & - & - & - \\
\hline Overall & 158 & 76 & 2.4 & 1.11 & 5.63 & 30 & 76 & 1 & - & - & 128 & 76 & 2.59 & 1.04 & 6.42 \\
\hline \multicolumn{16}{|l|}{ Paraquat } \\
\hline No & 123 & 66 & 1 & - & - & 24 & 66 & 1 & - & - & 99 & 66 & 1 & - & - \\
\hline Low & 28 & 6 & 2.91 & 1.03 & 8.2 & 6 & 6 & 1.95 & 0.38 & 10.04 & 22 & 6 & 2.83 & 0.96 & 8.37 \\
\hline Medium-high & 7 & 4 & 1.1 & 0.26 & 4.59 & 0 & 4 & - & - & - & 7 & 4 & 1.27 & 0.3 & 5.41 \\
\hline Overall & 158 & 76 & 1.51 & 0.8 & 2.87 & 30 & 76 & 1.52 & 0.35 & 6.58 & 128 & 76 & 1.52 & 0.79 & 2.94 \\
\hline \multicolumn{16}{|l|}{ Radon } \\
\hline No & 113 & 59 & 1 & - & - & 28 & 59 & 1 & - & - & 85 & 59 & 1 & - & - \\
\hline Low & 26 & 14 & 0.97 & 0.44 & 2.1 & 2 & 14 & 0.12 & 0.01 & 1.25 & 24 & 14 & 1.2 & 0.54 & 2.65 \\
\hline Medium-high & 19 & 3 & 9.5 & 1.18 & 76.82 & 0 & 3 & 0.12 & 0.01 & 1.25 & 19 & 3 & 9.37 & 1.16 & 75.85 \\
\hline Overall & 158 & 76 & 1.71 & 0.97 & 3.02 & 30 & 76 & 0.12 & 0.01 & 1.24 & 128 & 76 & 1.87 & 1.04 & 3.35 \\
\hline
\end{tabular}

${ }^{a}$ All the estimates were adjusted by sister cancer familiarity, age at diagnosis, province, sex, packyears and level of education

${ }^{\mathrm{b}}$ For this cumulative exposure was difficult perform multiple analysis by exposure dummy variables

All the italicized values represent statistical significant estimates

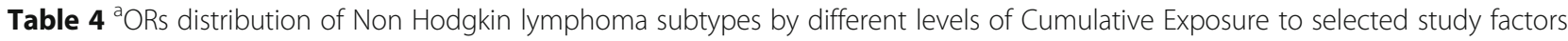
and agricultural occupation

\begin{tabular}{|c|c|c|c|c|c|c|c|c|c|c|c|c|c|c|c|}
\hline \multirow{3}{*}{$\begin{array}{l}\text { CUMULATIVE } \\
\text { EXPOSURE }\end{array}$} & \multirow{2}{*}{\multicolumn{5}{|c|}{$\begin{array}{l}\text { NON HODGKIN LYMPHOMA } \\
\text { NHL }\end{array}$}} & \multicolumn{10}{|c|}{ NON HODGKIN LYMPHOMA SUBTYPES } \\
\hline & & & & & & \multicolumn{5}{|l|}{$\overline{D L B C L}$} & \multicolumn{5}{|l|}{$F L$} \\
\hline & CASES & CONTROLS & $\mathrm{OR}^{\mathrm{a}}$ & $95 \% \mathrm{LCl}$ & $95 \% \cup C l$ & CASES & CONTROLS & $\mathrm{OR}^{\mathrm{a}}$ & $95 \% \mathrm{LCl}$ & $95 \% \cup \mathrm{UCl}$ & CASES & CONTROLS & $\mathrm{OR}^{\mathrm{a}}$ & $95 \% \mathrm{LCl}$ & $95 \% \cup C l$ \\
\hline \multicolumn{16}{|l|}{${ }^{\mathrm{b}}$ Captafol } \\
\hline No & 102 & 70 & 1.0 & - & - & 25 & 70 & 1.0 & - & - & 22 & 70 & 1.0 & - & - \\
\hline Low & 6 & 5 & 1.0 & 0.3 & 3.7 & 5 & 5 & 3.5 & 0.8 & 15.2 & 0 & 5 & 1.0 & - & - \\
\hline Medium-high & 14 & 1 & - & - & - & 5 & 1 & 1.0 & - & - & 4 & 1 & 1.0 & - & - \\
\hline Overall & 20 & 6 & 2.6 & 1.1 & 8.2 & 10 & 6 & 5.3 & 1.6 & 17.3 & 4 & 6 & 3.0 & 0.6 & 14.1 \\
\hline \multicolumn{16}{|l|}{ Paraquat } \\
\hline No & 99 & 66 & 1.0 & - & - & 26 & 66 & 1.0 & - & - & 19 & 66 & 1.0 & - & - \\
\hline Low & 22 & 6 & 2.8 & 0.9 & 8.2 & 7 & 6 & 3.8 & 1.0 & 15.3 & 6 & 6 & 4.6 & 1.1 & 20.2 \\
\hline Medium-high & 7 & 4 & 1.1 & 0.3 & 4.8 & 2 & 4 & 1.6 & 0.2 & 12.3 & 1 & 4 & 1.1 & 0.1 & 13.8 \\
\hline Overall & 29 & 10 & 2.1 & 0.9 & 5.3 & 9 & 10 & 2.7 & 0.7 & 9.6 & 7 & 10 & 3.3 & 0.9 & 12.3 \\
\hline \multicolumn{16}{|l|}{ Radon } \\
\hline No & 85 & 59 & 1.0 & - & - & 22 & 59 & 1.0 & - & - & 17 & 59 & 1.0 & - & - \\
\hline Low & 24 & 14 & 1.2 & 0.5 & 2.6 & 8 & 14 & 1.5 & 0.5 & 4.4 & 5 & 14 & 1.2 & 0.3 & 4.1 \\
\hline Medium-high & 19 & 3 & 8.8 & 1.1 & 71.4 & 5 & 3 & 13.7 & 1.3 & 143.0 & 4 & 3 & 12.7 & 1.2 & 137.2 \\
\hline Overall & 43 & 17 & 1.7 & 0.8 & 3.6 & 13 & 17 & 2.2 & 0.8 & 5.8 & 9 & 17 & 2.0 & 0.7 & 5.8 \\
\hline \multicolumn{16}{|c|}{ Agricultural occupation } \\
\hline No & 98 & 68 & 1.0 & - & - & 23 & 68 & 1.0 & - & - & 25 & 68 & 1.0 & - & - \\
\hline Yes & 14 & 4 & 2.4 & 0.6 & 9.3 & 8 & 4 & 9.3 & 2.0 & 43.6 & 0 & 4 & 1.2 & 0.7 & 2.0 \\
\hline
\end{tabular}

${ }^{b}$ For this cumulative exposure wasn't possible perform multiple analysis by exposure dummy variablesLegend: $H L$ Hodgkin Lymphoma, NHL Non Hodgkin Lymphoma, DLBCL Diffuse Large B-Cell Lymphoma, FL Follicular Lymphoma, CLL Chronic Lymphocitic Leukemia, SBCL Single B Cell Lymphoma, MM Multiple Mieloma 


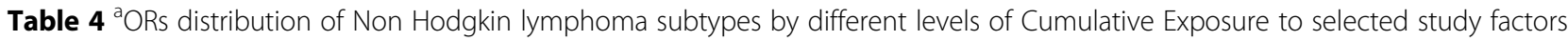
and agricultural occupation (Continued)

\begin{tabular}{|c|c|c|c|c|c|c|c|c|c|c|c|c|c|c|c|}
\hline \multirow{3}{*}{$\begin{array}{l}\text { CUMULATIVE } \\
\text { EXPOSURE }\end{array}$} & \multicolumn{15}{|c|}{ NON HODGKIN LYMPHOMA SUBTYPES } \\
\hline & \multicolumn{5}{|l|}{$C L L$} & \multicolumn{5}{|l|}{$S B C L$} & \multicolumn{5}{|l|}{ MM } \\
\hline & CASES & CONTROLS & $\mathrm{OR}^{\mathrm{a}}$ & $95 \% \mathrm{LCl}$ & $95 \%$ UCl & CASES & CONTROLS & $O R^{a}$ & $95 \% \mathrm{LCl}$ & $95 \%$ UCl & CASES & CONTROLS & $O R^{a}$ & $95 \% \mathrm{LCl}$ & $95 \% \cup C l$ \\
\hline \multicolumn{16}{|l|}{$\overline{{ }^{\mathrm{b}} \text { Captafol }}$} \\
\hline No & 38 & 70 & 1.0 & - & - & 8 & 70 & 1.0 & - & - & 9 & 70 & 1.0 & - & - \\
\hline Low & 0 & 5 & 1.0 & - & - & 0 & 5 & 1.0 & - & - & 1 & 5 & 3.0 & 0.1 & 59.1 \\
\hline Medium-high & 4 & 1 & 1.0 & - & - & 0 & 1 & 1.0 & - & - & 1 & 1 & 1.0 & - & - \\
\hline Overall & 4 & 6 & 1.4 & 0.3 & 7.0 & 0 & 6 & 1.0 & - & - & 2 & 6 & 10.9 & 1.0 & 125.8 \\
\hline \multicolumn{16}{|l|}{ Paraquat } \\
\hline No & 33 & 66 & 1.0 & - & - & 7 & 66 & 1.0 & - & - & 9 & 66 & 1.0 & - & - \\
\hline Low & 7 & 6 & 3.5 & 0.8 & 16.1 & 1 & 6 & - & - & - & 0 & 6 & 1.0 & - & - \\
\hline Medium-high & 2 & 4 & 0.9 & 0.1 & 6.8 & 0 & 4 & - & - & - & 2 & 4 & 3.3 & 0.2 & 63.8 \\
\hline Overall & 9 & 10 & 2.9 & 0.8 & 10.3 & 1 & 10 & 1.3 & 0.1 & 14.7 & 2 & 10 & 2.0 & 0.1 & 26.9 \\
\hline \multicolumn{16}{|l|}{ Radon } \\
\hline No & 29 & 59 & 1.0 & - & - & 4 & 59 & 1.0 & - & - & 8 & 59 & 1.0 & - & - \\
\hline Low & 6 & 14 & 0.9 & 0.3 & 2.9 & 2 & 14 & 2.9 & 0.3 & 29.7 & 2 & 14 & 0.6 & 0.1 & 5.5 \\
\hline Medium-high & 7 & 3 & 10.8 & 0.9 & 130.1 & 2 & 3 & 64.4 & 2.1 & 1959.6 & 1 & 3 & 106.1 & 1.3 & 8620.0 \\
\hline Overall & 13 & 14 & 1.5 & 0.5 & 4.0 & 4 & 17 & 6.6 & 0.9 & 45.6 & 3 & 17 & 1.4 & 0.2 & 9.0 \\
\hline \multicolumn{16}{|c|}{ Agricultural occupation } \\
\hline No & 34 & 68 & 1.0 & - & - & 8 & 68 & 1.0 & - & - & 8 & 68 & 1.00 & - & - \\
\hline Yes & 4 & 4 & 2.1 & 0.4 & 11.0 & 0 & 4 & 1.0 & - & - & 2 & 4 & 6.16 & 0.70 & 54.15 \\
\hline
\end{tabular}

All the italicized values represent statistical significant estimates

DLBCL $[\mathrm{OR}=3.8(1-15.3)]$ and FL $[\mathrm{OR}=4.6(1.1-20.2)]$ subtypes. Medium-high levels of exposure to radon were associated with DLBCL $[\mathrm{OR}=13.7$ (1.3-143.0)] and SBCL $[O R=64.4(2.1-1959.6)]$. th $=$ tlb $=$

Table 5 illustrates the association between agricultural occupations and the risk of different lymphoma subtypes. This occupation category was associated with DLBCL $[\mathrm{OR}=10.9$ (2.3-51.6)] and MM [OR = 16.5 (1.4195.7)]. This finding is consistent with the study of Mester et al. [27].

\section{Discussion}

The observed association in this study between DLBCL subtype and agricultural occupations [OR = $10.9(2.3-51.6)]$ is consistent with the results of a large pooled analysis of international studies [20, 26]. Moreover, general farm workers were at high risk of developing $\mathrm{MM}[\mathrm{OR}=16.5$ (1.4-195.7)], as reported by Morton et al. [28].

A death certificate case-control study suggests that young agricultural worker residents from Southern Brazil were more likely to die from NHL than nonagricultural workers [29]. A meta-analysis suggested that total organo-chlorine pesticides (OCPs) was significantly positively associated with NHL risk [30].

Our study also showed a significant association between the occurrence of lymphoma and exposure to
Table 5 Association estimates $\left(O R s^{a}\right)$ between occupation as agricultural worker and different lymphoma subtypes

\begin{tabular}{|c|c|c|c|c|c|c|c|}
\hline \multicolumn{8}{|l|}{ Agricultural worker } \\
\hline & & Total & No & Yes & OR & $95 \%$ LCl & $95 \% \cup C l$ \\
\hline \multirow[t]{2}{*}{ ALL LYMPHOMAS } & No & 72 & 68 & 4 & 1 & - & - \\
\hline & Yes & 141 & 127 & 14 & 2.3 & 0.6 & 8.5 \\
\hline \multirow[t]{2}{*}{$\mathrm{HL}$} & No & 72 & 68 & 4 & 1 & - & - \\
\hline & Yes & 24 & 24 & 0 & - & - & - \\
\hline \multirow[t]{2}{*}{$\mathrm{NHL}$} & No & 72 & 68 & 4 & 1 & - & - \\
\hline & Yes & 117 & 103 & 14 & 2.7 & 0.7 & 10.1 \\
\hline \multirow[t]{2}{*}{ NHL-DLBCL } & No & 72 & 68 & 4 & 1 & - & - \\
\hline & Yes & 31 & 23 & 8 & 10.9 & 2.3 & 51.6 \\
\hline \multirow[t]{2}{*}{$\mathrm{NHL}-\mathrm{FL}$} & No & 72 & 68 & 4 & 1 & - & - \\
\hline & Yes & 25 & 25 & 0 & - & - & - \\
\hline \multirow[t]{2}{*}{ NHL-CLL } & No & 72 & 68 & 4 & 1 & - & - \\
\hline & Yes & 37 & 33 & 4 & 2.4 & 0.5 & 13.3 \\
\hline \multirow[t]{2}{*}{ NHL-SBCL } & No & 72 & 68 & 4 & 1 & - & - \\
\hline & Yes & 8 & 8 & 0 & - & - & - \\
\hline \multirow[t]{2}{*}{ NHL-MM } & No & 72 & 68 & 4 & 1 & - & - \\
\hline & Yes & 10 & 8 & 2 & 16.5 & 1.4 & 195.7 \\
\hline
\end{tabular}

${ }^{a}$ All the estimates were adjusted by sister cancer familiarity, age at diagnosis, province, sex, packyears and level of education

Legend: HL Hodgkin Lymphoma, NHL Non Hodgkin Lymphoma, DLBCL Diffuse Large B-Cell Lymphoma, FL Follicular Lymphoma, CLL Chronic Lymphocitic Leukemia, SBCL Single B Cell Lymphoma, MM Multiple Mieloma All the italicized values represent statistical significant estimates 
Captafol, which is used as a fungicide in agriculture, according to Mc Duffie et al. 2001 [OR $=2.51(1.32-4.76)]$ [31]. In our data, a positive association was also observed with exposure to Paraquat, an herbicide, but there was an inverse trend with exposure level. Uncertainty in the interpretation of our findings might be related to the small study size and the crude definition of exposure. No data are available in the literature regarding the dose-response correlation of pesticides and lymphoma. Recently, however, some studies have reported a relationship between exposure to fungicides, herbicides or insecticides and NHL occurrence [32-35].

Moreover, sales of Captafol and Folpet, both fungicides, which have similar molecular structures, in the Apulia region increased from $80 \mathrm{~kg}$ to $741 \mathrm{~kg}$ [36] from 2002 to 2012, while sales of Paraquat in 2002 were $662 \mathrm{~kg}$ [37]. The extensive use of this pesticide in the Apulia region also explains its popular use for suicidal purposes [38] and horse poisonings [39]; in France, there was no apparent change in the number of suicide attempts involving Paraquat after its ban in July 2007 [40]. Captafol is a human carcinogen, in fact it was classified by the IARC as probably carcinogenic to humans (Group 2A). The Captafol production for use as a fungicide in the United States stopped in 1987. Its continued use from existing stocks was allowed, but in 1999 the Environmental Protection Agency banned its use on all crops except onions, potatoes, and tomatoes. In 2006 even these exceptions were disallowed, so currently its use on all crops is banned in the United States. Several other countries have followed suit since 2000, and as of 2010, no countries are known to allow the use of Captafol on food crops.

The carcinogenic mechanism of Captafol is attributed to its interaction with the thiol groups of glutathione and cysteine, which reduces the defence against oxidative agents, and the N-S bond formation with other biological substrates, both leading to the formation of metabolites such as tetrahydrophthalamide, which is considered a human carcinogen [41].

Paraquat (N,N' -dimethyl-4,4'-bipyridinium dichloride) is an herbicide widely used in agriculture. It is derived from the alkylating agent dimethyl sulphate.

Results from the Agricultural Health Study showed an increased risk of NHL among Paraquat-exposed pesticide applicators [42]. One study suggested that Paraquat increases superoxide dismutase activity and radiation resistance in mouse lymphoma cells [43]. Another study suggested that increased levels of metallothionein, glutathione S-transferase, $\mathrm{Cu}, \mathrm{Zn}$-SOD and $\mathrm{Mn}$-SOD might be protective against Paraquat toxicity in acute myelogenous leukaemia (AML) cells [44]. Moreover, the possibility of Paraquat-induced DNA damage has been suggested [45].

Acute exposure to Paraquat accounted for several cases of fatal poisoning, while chronic exposure appears to be associated with respiratory disease and Parkinson's disease [46]. Animal studies have shown DNA alterations in treated animals. In the past, exposure to Paraquat has been associated with melanoma, leukaemia, and cancer of the penis, cervix and lung. More recent studies found a significantly increased risk of developing NHL among subjects exposed to this substance. Therefore, our understanding of Paraquat carcinogenicity is limited, and further studies are warranted [41].

As indicated in Appendix 1 of the work of Mirabelli et al. [19], exposure to Radon, which was higher among agricultural workers, food and beverage production workers, and electricity workers, was also associated with DLBCL $[\mathrm{OR}=2.5(1.2-5.4)]$ and SBCL $[\mathrm{OR}=5.7$ (1.3-25.6)]. Radon is a product of the radioactive decay of radium. Radon is easily inhaled. The level of the Radon-gas hazard differs from location to location. Despite its short lifetime, radon gas from natural sources can accumulate in buildings, especially, due to its high density, in low areas such as basements and crawl spaces. Radon can also occur in ground water. Epidemiological studies have shown a clear link between breathing high concentrations of Radon and incidence of lung cancer. Radon is a contaminant that affects indoor air quality worldwide. According to the United States Environmental Protection Agency, Radon is the second most frequent cause of lung cancer, after cigarette smoking, causing 21,000 lung cancer deaths per year in the United States. As Radon itself decays, it produces other radioactive elements called Radon daughters (also known as Radon progeny) or decay products. Unlike the gaseous Radon itself, Radon daughters are solids and stick to surfaces, such as dust particles in the air. The Radon assessment was currently carried out in the studied Apulia areas and only in particular situations the concentration of Radon was above $300 \mathrm{~Bq} / \mathrm{m}^{3}$. But for agricultural workers this exposure was prolonged in time. Moreover, there was suggestive, though statistically non-significant, evidence of a significant increase of DLBCL among children with a high residential indoor exposure to Radon [47] and an increased risk of CLL and HL incidence, and NHL mortality with increasing $\gamma$-ray dose among Uranium miners [48].

\section{Conclusions}

This is a preliminary report of occupational risk factors for lymphoma in the provinces of Taranto and Bari (Apulia region, Southern Italy). Although limited in size and utilizing a crude method of retrospective exposure assessment, this work revealed that agricultural workers exposed to Captafol, Paraquat and radon could develop lymphoma subtypes, especially DLBCL. These findings confirm existing knowledge and suggest new hypotheses 
for research about occupational factors suspected to be associated with lymphoma risk.

One of the weaknesses of the study is the instability of the estimates even when they were significant. Such instability prompts us to be cautious about the conclusions even though they are consistent with previous studies.

\section{Abbreviations}

AHR: Aryl hydrocarbons receptors; AIDS: Acquired immuno-deficiency syndrome; AIRC: Associazione Italiana per la Ricerca sul Cancro;

AIRTUM: Associazione Italiana Registri Tumori; AML: Acute myeloid leukaemia; CAREX: CARcinogen EXposure; CEl: Cumulative exposure index; CLL: Chronic lymphocytic leukaemia; DIM: Interdisciplinary Department of Medicine; DLBCL: Diffuse large B-cell lymphoma; FL: Follicular lymphoma; GWAS: Genome-Wide Association Study; HL: Hodgkin Lymphoma; IARC: International Agency for Research on Cancer; MALT: Mucosa-Associated Lymphoma Tissue; MGUS: Monoclonal Gammopathy of Undetermined Significance; MM: Multiple myeloma; NHL: Non-Hodgkin Lymphoma; OCPs: Organo-Chlorine Pesticides; OR: Odds ratio; PAHs: Polycyclic aromatic hydrocarbons; PCB: Polychlorinated biphenyls; PRIN: Research Project of National Interest; SBCL: Small B-cell lymphoma; WHO: World Health Organization

\section{Acknowledgements}

We thank all the workers of the three hospital units involved in this study for their cooperation.

\section{Funding}

Research project of national interest (PRIN 2007-2009; AIRC): "The Multicentre Italian Study on gene-environment interactions in Lymphoma etiology".

\section{Availability of data and materials}

Please contact author for data requests.

\section{Authors' contributions}

All authors contributed equally in planning, conduction and data analysis of the study. All authors read and approved the final manuscript.

\section{Authors' information}

All the authors are interested in the development of the scientific fields related to this work, including cancer epidemiology and haematology.

\section{Ethics approval and consent to participate}

- Regione Puglia.

Azienda Ospedaliera "Ospedale Policlinico Consorziale" di Bari.

COMITATO ETICO INDIPENDENTE LOCALE.

Prot.n. 1193/C.E. 07/10/2008.

- Regione Puglia.

Azienda Ospedaliera "Ospedale Policlinico Consorziale" di Bari.

COMITATO ETICO INDIPENDENTE LOCALE.

Prot.n. 25/C.E. 09/01/2012.

\section{Consent for publication}

Not applicable.

\section{Competing interests}

The authors declare that they have no competing interests.

\section{Publisher's Note}

Springer Nature remains neutral with regard to jurisdictional claims in published maps and institutional affiliations.

\section{Author details}

'Department of Interdisciplinary Medicine (DIM), Section "B. Ramazzini", Regional University Hospital "Policlinico - Giovanni XXIII", Unit of Occupational Medicine, University of Bari, Piazza G. Cesare, 11, 70124 Bari, Italy. ${ }^{2}$ Department of Emergency and Transplantation (DETO), Regional Universitary Hospital "Policlinico - Giovanni XXIII', Unit of Hematology, University of Bari, Piazza G.
Cesare, 11, 70124 Bari, Italy. ${ }^{3}$ ASL Taranto, Moscati Hospital, Unity of Haematology, Via Paisiello 1, 74100 Taranto, Italy. ${ }^{4}$ Department of Emergency and Transplantation (DETO), Regional University Hospital "Policlinico - Giovanni XXIII ", Unit of Pathology, University of Bari, Piazza G. Cesare, 11, 70124 Bari, Italy. ${ }^{5}$ Department of Public Health, Clinical \& Molecular Medicine, Occupational Health Section, University of Cagliari, 09100 Cagliari, Italy. ${ }^{6}$ Interdisciplinary Department of Medicine (DIM), University Hospital. Policlinico-Giovanni XXIII, University of Bari, Piazza Giulio Cesare, 11, 70124 Bari, Italy.

Received: 27 July 2017 Accepted: 24 October 2017

Published online: 23 November 2017

\section{References}

1. Gruppo di lavoro AIOM-AIRTUM. I numeri del cancro in Italia. Brescia: Intermedia editore; 2014. p. 61-4.

2. Assennato $G$, Bisceglia L, Bruno D, et al. Incidenza, mortalità e sopravvivenza delle patologie oncologiche in Puglia. Registro tumori Puglia. Rapporto tumori; 2015. p. 259-82.

3. Campagna M, Cocco P, Zucca M, Angelucci E, Gabbas A, Latte GC, et al. Risk of lymphoma subtypes and dietary habits in a Mediterranean area. Cancer Epidemiol. 2015;39:1093-8.

4. Costas L, Lambert BH, Birmann BM, Moysich KB, De Roos AJ, Hofmann JN, et al. A pooled analysis of reproductive factors, exogenous hormone use, and risk of multiple myeloma among women in the international multiple myeloma consortium. Cancer Epidemiol Biomark Prev. 2016;25:217-21.

5. Kane V, Roman E, Becker N, Bernstein L, Boffetta P, Bracci PM, et al. Menstrual and reproductive factors, and hormonal contraception use: associations with non-Hodgkin lymphoma in a pooled analysis of InterLymph case-control studies. Ann Oncol. 2012;23:2362-74.

6. Beane Freeman LE, Deroos AJ, Koutros S, Blair A, Ward MH, Alavanja M, Hoppin JA. Poultry and livestock exposure and cancer risk among farmers in the agricultural health study. Cancer Causes Control. 2012;23:663-70.

7. Becker N, Falster MO, Vajdic CM, de Sanjose S, Martínez-Maza O, Bracci PM, et al. Self-reported history of infections and the risk of non-Hodgkin lymphoma: an InterLymph pooled analysis. Int J Cancer. 2012;131:2342-8.

8. Boffetta P, van der Hel O, Kricker A, Nieters A, de Sanjosé S, Maynadié M, et al. Exposure to ultraviolet radiation and risk of malignant lymphoma and multiple myeloma: a multicentre European case-control study. Int J Epidemiol. 2008;37:1080-94.

9. Cocco P, Brennan P, Ibba A, de Sanjosé LS, Maynadié M, Nieters A, et al. Plasma polychlorobiphenyl and organochlorine pesticide level and risk of major lymphoma subtypes. Occup Environ Med. 2008;65(2):132-40.

10. Blair A, Freeman LB. Epidemiologic studies of cancer in agricultural populations: observations and future directions. J Agromedicine. 2009;14(2): $125-31$

11. Koutros S, Alavanja MCR, Lubin JH, Sandler DP, Hoppin JA, Lynch CF, et al. An update of cancer incidence in the agricultural health study. J Occup Environ Med. 2010;52(11):1098-105.

12. Waggoner JK, Kullman GJ, Henneberger PK, Umbach DM, Blair A, Alavanja MC, et al. Mortality in the agricultural health study, 1993-2007. Am J Epidemiol. 2011;173(1):71-83.

13. Weichenthal S, Moase C, Chan P. A review of pesticide exposure and cancer incidence in the agricultural health study cohort. Environ Health Perspect. 2010;118(8):1117-25

14. Schenk M, Purdue MP, Colt JS, Hartge P, Blair A, Stewart P, et al. Occupation/industry and risk of non Hodgkin lymphoma in the United States. Occup Environ Med. 2009;66(1):23-31.

15. Hohenadel K, Harris SA, McLaughlin JR, Spinelli JJ, Pahwa P, Dosman JA, et al. Exposure to multiple pesticides and risk of non-Hodgkin lymphoma in men from six Canadian provinces. Int J Environ Res Public Health. 2011;8(6): 2320-30.

16. Rieutort D, Moyne O, Cocco P, de Gaudemaris R, Bicout DJ. Ranking occupational contexts associated with risk of non-Hodgkin lymphoma. Am J Ind Med. 2016;59(7):561-74. doi:10.1002/ajim.22604.

17. Campo E, Swerdlow SH, Harris NL, Pileri S, Stein H, Jaffe ES. The 2008 WHO classification of lymphoid neoplasms and beyond: evolving concepts and practical applications. Blood. 2011;117(19):5019-32.

18. Castaño-Vinyals G, Nieuwenhuiisen MJ, Moreno V, Carrasco E, Guinó E, Kogevinas M, Villanueva CM. Participation rates in the selection of population controls in a case-control study of colorectal cancer using two recruitment methods. Gac Sanit. 2011;25(5):353-6. 
19. Mirabelli D, Kauppinen T. Occupational exposures to carcinogens in Italy: an update of CAREX database. Int J Occup Environ Health. 2005;11(1):53-63.

20. Peters CE, Ge CB, Hall AL, Davies HW, Demers PA. CAREX Canada: an enhanced model for assessing occupational carcinogen exposure. Occup Environ Med. 2015;72(1):64-71.

21. Blanco-Romero LE, Vega LE, Lozano-Chavarría LM, Partanen TJ. CAREX Nicaragua and Panama: worker exposures to carcinogenic substances and pesticides. Int J Occup Environ Health. 2011;17(3):251-7.

22. t'Mannetje A, De Roos AJ, Boffetta P, Vermeulen R, Benke G, Fritschi $L$, et al. Occupation and risk of non-Hodgkin lymphoma and its subtypes: a pooled analysis from the InterLymph consortium. Environ Health Perspect. 2015; 124(4):396-405.

23. Albini A, Rosano C, Angelini C, Amaro A, Esposito Al, Maramotti S, et al. Exogenous hormonal regulation in breast cancer cells by phythoestrogens and endocrine disruptors. Curr Med Chem. 2014;21(9):1129-45.

24. Engel LS, Hill DA, Hoppin JA, Lubin JH, Lynch CF, Pierce J, et al. Pesticide use and breast cancer risk among farmers' wives in the agricultural health study. Am J Epidemiol. 2005;161:121-35.

25. Hye SK, Soon WL, Yoon JC, Shin SW, Kim YH, Cho MS, et al. Novel germline mutation of BRCA1 gene in a 56-year-old woman with breast cancer, ovarian cancer, and diffuse large B-cell lymphoma. Cancer Res Treat. 2014;47(3):534-8.

26. Tamaoki M, Nio Y, Tsuboi K, Nio M, Tamaoki M, Maruyama R, et al. A rare case of non-invasive ductal carcinoma of the breast coexisting with follicular lymphoma: a case report with a review of the literature. Oncol Lett. 2014;7:1001-6.

27. Mester B, Nieters A, Deeg E, Elsner G, Becker N, Seidler A, et al. Occupation and malignant lymphoma: a population based case control study in Germany. Occup Environ Med. 2006;63(1):17-26.

28. Morton LM, Slager SL, Cerhan JR, Wang SS, Vajdic CM, Skibola CF, et al. Etiologic heterogeneity among non-Hodgkin lymphoma subtypes: the Interlymph non-Hodgkin lymphoma subtypes project. J Nat Cancer Inst Monogr. 2014;48:130-44

29. Boccolini PM, Boccolini CS, Chrisman JR, Koifman RJ, Meyer A. Non-Hodgkin lymphoma among Brazilian agricultural workers: a death certificate casecontrol study. Arch Environ Occup Health. 2017;72(3):139-44.

30. Luo D, Zhou T, Tao Y, Feng Y, Shen X, Mei S. Exposure to organochlorine pesticides and non-Hodgkin lymphoma: a meta-analysis of observational studies. Sci Rep. 2016;6:257-68.

31. McDuffie HH, Pahwa P, McLaughlin JR, Spinelli JJ, Fincham S, Dosman JA, et al. Non-Hodgkin's lymphoma and specific pesticide exposures in men: cross-Canada study of pesticides and health. Cancer Epidemiol Biomark Prev. 2001;10(11):1155-63.

32. Alavanja MC, Hofmann JN, Lynch CF, Spinelli JJ, Fincham S, Dosman JA, et al. Non-hodgkin lymphoma risk and insecticide, fungicide and fumigant use in the agricultural health study. PLoS One. 2014;9(10):e109332.

33. Navaranjan G, Hohenadel K, Blair A, Demers PA, Spinelli JJ, Pahwa P, et al. Exposures to multiple pesticides and the risk of Hodgkin lymphoma in Canadian men. Cancer Causes Control. 2013;24(9):1661-73.

34. Schinasi LH, De Roos AJ, Ray RM, Edlefsen KL, Parks CG, Howard BV, et al. Insecticide exposure and farm history in relation to risk of lymphomas and leukemias in theWomen's health initiative observational study cohort. Ann Epidemiol. 2015;25(11):803-10.

35. Schinasi L, Leon ME. Non-Hodgkin lymphoma and occupational exposure to agricultural pesticide chemical groups and active ingredients: a systematic review and meta-analysis. Int J Environ Res Public Health. 2014; 11(4):4449-527.

36. Alessio-Apostoli. Piccin, editor. Manual of occupational medicine and industrial hygiene. For technical prevention. $7^{\text {th }}$ ed.; 2009. p. 165.

37. Provincial Agency for Environmental Protection, Trento. Available from: http://www.appa.provincia.tn.it/fitofarmaci/programmazione_dei_controlli_ ambientali/Criteri_vendita_prodotti_fitosanitari/pagina122.html. Accessed 20 Nov 2017.

38. Settimi L, Davanzo F, Urbani E, et al. Sistema informativo nazionale per la sorveglianza delle esposizioni pericolose e delle intossicazioni: casi rilevati nel 2009. Quarto rapporto annuale. Istituto Superiore di Sanità. Rapporto Istisan. http://www.iss.it/binary/publ/cont/13_8_web.pdf.

39. Padalino B, Bozzo G, Monaco D, Ceci E. Avvelenamento da Paraquat in cavalli da carne pugliesi. Ippologia; 2012;23(3):15-21.

40. Kervégant M, Merigot L, Glaizal M, Schmitt C, Tichadou L, de Haro L. Paraquat poisonings in France during the European ban: experience of the poison control center in Marseille. J Med Toxicol. 2013;9(2):144-7.
41. National Toxicological Program. Captafol. Rep Carcinog. 2011;12:83-6.

42. Park SK, Kang D, Beane-Freeman L, Blair A, Hoppin JA, Sandler DP, et al. Cancer incidence among Paraquat exposed pesticide applicators in the agricultural health study. Int J Occup Environ Health. 2009;15(3):274-81.

43. Jaworska A, Rosiek O. Paraquat increases superoxide dismutase activity and radiation resistance in two mouse lymphoma L5178Y cell strains of different radiosensitivities. Int J Radiat Biol. 1991;60(6):899-906.

44. Choi CH, Kim HS, Kweon OS, Lee TB, You HJ, Rha HS, et al. Reactive oxygen species-specific mechanisms of drug resistance in Paraquat-resistant acute Myelogenous leukemia sublines. Mol Cells. 2000;10(I):38-46.

45. Ross WE, Block ER, Chang RY. Paraquat-induced DNA damage in mammalian cells. Biochem Biophys Res Commun. 1979;91(4):1302-8.

46. Rudyk C, Litteljohn D, Syed S, Dwyer Z, Hayley S. Paraquat and psychological stressor interactions as pertains to Parkinsonian co-morbidity. Neurobiol Stress. 2015;2:85-93.

47. Peckham EC, Scheurer ME, Danysh HE, Lubega J, Langlois PH, Lupo PJ, et al. Residential radon exposure and incidence of childhood lymphoma in Texas, 1995-2011. Int J Environ Health. 2015;12:12110-26.

48. Zablotska LB, Lane RS, Frost SE, Thompson PA. Leukemia, lymphoma and multiple myeloma mortality (1950-1999) and incidence (1969-1999) in the Eldorado uranium workers cohort. Environ Res. 2014;130:43-50.

\section{Submit your next manuscript to BioMed Central and we will help you at every step:}

- We accept pre-submission inquiries

- Our selector tool helps you to find the most relevant journal

- We provide round the clock customer support

- Convenient online submission

- Thorough peer review

- Inclusion in PubMed and all major indexing services

- Maximum visibility for your research

Submit your manuscript at www.biomedcentral.com/submit
Biomed Central 